\title{
Mikrotremor, Çok Kanallı Yüzey Dalgaları (ÇKYD) ve Mikrogravite Yöntemleri Kullanılarak Zemin Dinamik Özelliklerinin İrdelenmesi: Karșıyaka-İzmir Örneği
}

\author{
Examining the Dynamic Properties of Soil by Using Microtremor, \\ Multichannel Analysis of Surface Waves (MASW) and Microgravity \\ Methods: A Case Study in Karșlyaka-izmir
}

AYKUT TUNÇEL ${ }^{1 *}$, OYA PAMUKÇU', TOLGA GÖNENÇ ${ }^{1}$, MUSTAFA AKGÜN'

${ }^{1}$ Dokuz Eylül Üniversitesi Mühendislik Fakültesi Jeofizik Mühendisliği Bölümü, 35160 İzmir

$\begin{array}{ll}\text { Geliș (received) } & : 24 \text { Kasım (November) } 2015 \\ \text { Kabul (accepted) } & : 11 \text { Temmuz (July) } 2016\end{array}$

öz

Bu çalıșma kapsamında yeraltı tabakalarının dinamik koșullar altındaki özelliklerini incelemek için İzmir Körfezi kuzeyinde D-B yönünde yaklașık 4 km ve K-G yönünde 5 km ile sınırlandırımıș 20 km²'lik bir alandan jeofizik veriler toplanmıștır. Çalıșma kapsamında Rayleigh tipi yüzey dalgalarının dispersif özelliğini kullanan Çok Kanallı Yüzey Dalgaları (ÇKYD) yöntemi kullanılmıștır. ÇKYD yöntemiyle 30 metre derinliğe kadar olan makaslama dalgası hızları $\left(V_{s} 30\right)$ elde edilmiș ve bu hız değerleri kullanılarak alana ait Zemin Hâkim Titreșim Periyodu (ZHTP) ve yoğunluk değișimleri hesaplanmıștır. ZHTP değerleri çalıșma alanı içinde 112 noktada mikrotremor yöntemi ile kaydedilen veriler kullanılarak hesaplanmıștır. Mikrotremor ve ÇKYD yöntemlerinden elde edilen dağıım haritalarıyla ortak yorumlayabilmek için, mikrogravite yöntemi verileri kullanılarak Bouguer gravite dağıım haritası olușturulmuștur. Mikrotremor tek nokta ölçümleri ile elde edilen ZHTP değerlerinin 1 sn'den daha büyük olduğu noktalarla $V_{s} 30$ hızlarının 700 m/sn'den daha düșük olduğu yerlerin örtüștüğü dağılım haritalarında gözlenmektedir. Bu örtüșmenin gözlendiği yerlerde alüvyon zeminlerin yer aldığı ve mühendislik anakayası derinliğinin 30 m'den fazla olabileceği söylenebilir. Çalıșma alanı, uygulanan yöntemler sonucunda elde edilen parametrelere göre fiziksel özellikleri açısından KB-GD yönlü çizgisel bir sınır ile iki ayrı alana ayrılabileceği dağılım haritalarına bakılarak söylenebilir. Bu çizginin kuzeyinde daha yüksek hız değerleri ve ayrıca bu hız değerlerinden elde edilen daha yüksek yoğunluk ve daha düșük ZHTP değerleri gözlenmiștir. Bu bulgular ıșığında çalıșma alanının kuzey kesimlerinin göreli gerilme dayanımı yüksek jeolojik birimlerden oluștuğundan, güney bölümde ise özellikle İzmir Körfezi kıyılarına doğru göreli gerilme dayanımı düșük jeolojik birimlerin varlığından söz edebiliriz. Çalıșma kapsamında elde edilen bulgular bölgenin jeolojisi ve tektonik özellikleri ile uyum sağlamaktadır.

Anahtar Kelimeler: Çok Kanallı Yüzey Dalgaları (ÇKYD), İzmir, Karșıyaka, Mikrogravite, Mikrotremor.

\begin{abstract}
In this study, to investigate the characteristics of the subterranean structures under dynamic conditions the geophysical data were collected in approximately $4 \mathrm{~km}$ along EW direction and $5 \mathrm{~km}$ along NS direction in an area of $20 \mathrm{~km}^{2}$ in the North of izmir Bay. At the scope of the study Multi-Channel Analyses of Surface Waves (MASW) method which uses the dispersive feature of Rayleigh type surface waves is used. Shear wave velocity $\left(V_{S} 30\right)$ up to 30 meters deep is obtained with MASW method, using these velocity values predominant site period (PSP) and density changes are calculated. Furthermore PSP changes are calculated using the recorded microtremor method data at 112 points in the study area. To examine the site structure of the study area and common interpretation seismic velocity and the other distribution maps derived from the seismic velocities with Bouguer gravity maps which were created using microgravity method data. To common interpret the distribution maps obtained from Microtremor and MASW methods with Bouguer gravity distribution map which were created using microgravity method. It is observed at distribution maps that the points where PSP values obtained from Microtremor single point measurements are greater than 1 second overlaps the locations where $V_{s} 30$ velocities are lower than $700 \mathrm{~m} / \mathrm{sec}$. At the locations that overlapping can said the alluvium soil takes place and engineering bedrock depth is more than 30 meters. It can be said that the study area can be divided into two separate parts by a NW-SE trending boundary line in terms of physical properties according to the parameters
\end{abstract}

\footnotetext{
* A.Tunçel

e-posta: aykut.tuncel@deu.edu.tr
} 
obtained from the methods applied at the study area by looking at the distribution maps. Higher velocity values and also higher density and lower PSP values obtained by these velocities were observed at the north of this line. These findings led us that the northern part of the area consists of geological units which are more resistant to earthquakes but towards the bay coast at southern part of the area there exists weaker geological units. The findings obtained according to the scope of the study are compatible with the geology and tectonic features of the region.

Keywords: Izmir, Karșiyaka, Multichannel Analysis of Surface Waves (MASW), Microgravity, Microtremor.

\section{Giriș}

Bir gözlem noktasında kaydedilen deprem kaydı, kaynağından çıkıp sismometre tarafından kaydedilene kadar yeraltı tabakalarının birçok fiziksel özelliğinden etkilenir. Yapılarda hasar olușturan depremlerdeki en önemli etkenler; deprem kaynağının kinematik ve dinamik özellikleri, deprem dalgalarının geçtiği ortamların fiziksel ve geometrik parametreleri, dalgaların soğurulması, gözlem noktasındaki sığ yer yapısının fiziksel ve yapısal özellikleri ile o ortamın bölgesel davranıș özellikleri olarak sayılabilir.

Bir yapının deprem gerilme dayanımının yüksek olabilmesi sadece yapıya ait mühendislik hesaplarının değil aynı zamanda çevredeki yapılașma, bina yükleri ve özellikle üzerine inşa edileceği zeminin özelliklerinin hesaba katılması ile mümkündür. Bu da zeminin dinamik yükler altında nasıl davranacağının önceden bilinmesinin önemini ortaya koymaktadır. Zemin tabakası, deprem dalgasının genlik, periyot vb. özelliklerini değiștirerek üzerinde tașıyacağı yapıya aktarır. Sismik dalgaların özelliklerinde zemin tabakalarından geçerken zeminin fiziksel özelliklerine göre değișimler meydana gelmektedir. Bu sebeplerle bir mikro bölgeleme çalıșması Aki (1988) ve Bolt (1999) tarafından da belirtildiği gibi deprem dalgalarının özelliklerini ve zeminin fiziksel özelliklerini mutlaka dikkate almalıdır.

Günümüzde Deprem Bölgelerinde Yapılacak Binalar Hakkında Yönetmelik (DBYBHY, 2007) ve Eurocode 8 (2004) yönetmeliklerine göre zeminlerin deprem sırasında yapacağı dinamik davranıș spektrumlarının ön kestirilmesinde 30 metreye kadar olan makaslama dalgası hız değerleri $\left(\mathrm{V}_{\mathrm{s}} 30\right)$ ile ZHTP $\left(\mathrm{T}_{0}\right)$ değerleri yaygın olarak kullanılır.

Zemin dinamik parametrelerinin (zemin hâkim titreșim periyodu, yoğunluk vb.) tamamı makaslama dalga hızı ile ilișkilidir. Bu sebeple, makaslama dalga hızının $\left(V_{S}\right)$ derinlik ile değișimi büyük önem tașır. Zemin davranıșının tanımlanmasında, $V_{s}$ değeri, zemin büyütmesi, yoğunluk ve zemin hâkim titreșim periyodu bilgileri birlikte kullanılırlar (Joyner ve Furnal, 1984, Borcherd vd., 1991). Bu nedenle, sismik kırılma veya ÇKYD yöntemleri zemin dinamik parametrelerinin tanımlanması çalıșmalarında (Tunçel, 2014) kullanılan yöntemlerdendir. Zemine ait makaslama dalgası hızının derinliğe bağlı değişiminin tanımlanması derinliğe bağlı yoğunluk değerlerinin elde edilmesine olanak verir. ÇKYD yöntemiyle elde edilen makaslama dalgası hızlarından elde edilen yoğunluk dağılımı ve mikrogravite yöntemiyle elde edilen gravite değerlerinin değișiminin birbirleriyle uyumlu olması beklenmektedir.

İzmir ili birinci derece deprem bölgesinde yer almakta ve sıklıkla küçük ve orta ölçekte depremlerden etkilenmektedir. Nüfus artışı, kontrolsüz yapılaşma ve zeminin deprem anındaki dinamik etkilerinin göz önüne alınmadığı durumlar deprem riskini arttıracaktır. Gerekli önlemlerin alınması durumunda, bir deprem sonucu oluşabilecek sosyo-ekonomik hasar en aza indirilip, yalnızca İzmir şehri için değil, tüm ülke ekonomisi için ciddi kazançlar sağlanılabilecektir.

Bu çalıșma kapsamında, Batı Anadolu içinde yer alan ve Marmara bölgesi gibi deprem riski yüksek olan İzmir ili Karșıyaka ilçesinde (Șekil 1) ÇKYD, mikrotremor ve mikrogravite yöntemleri kullanılarak çalıșma alanında yer alan jeolojik birimlerin dinamik koșullardaki özelliklerinin tanımlanması için jeofizik yöntemler ile veri toplanmıștır. ÇKYD yöntemi kullanılarak 30 m derinliğe kadar olan makaslama dalgası hızları $\left(\mathrm{V}_{s} 30\right)$ değișimleri elde edilmiștir. Bu hız değerleri kullanılarak çalıșma alanında $30 \mathrm{~m}$ derinliğe kadar olan ZHTP ve yoğunluk değișimleri hesaplanmıștır. Elde edilen $\mathrm{V}_{\mathrm{s}} 30$, ZHTP ve yoğunluk parametrelerinin çalıșma alanındaki değișimleri dağılım haritaları (Șekil 3, 4, 5) ile verilmiștir. Mikrotremor yöntemi verileri ișlenerek ZHTP değerleri elde edilmiș ve dağılım haritası olarak Șekil 6'da verilmiștir. Mikrogravite verilerine 2. derece trend analizi uygulanarak çalıșma alanına ait Bouguer gravite anomali haritası elde edilmiștir (Șekil 7). 

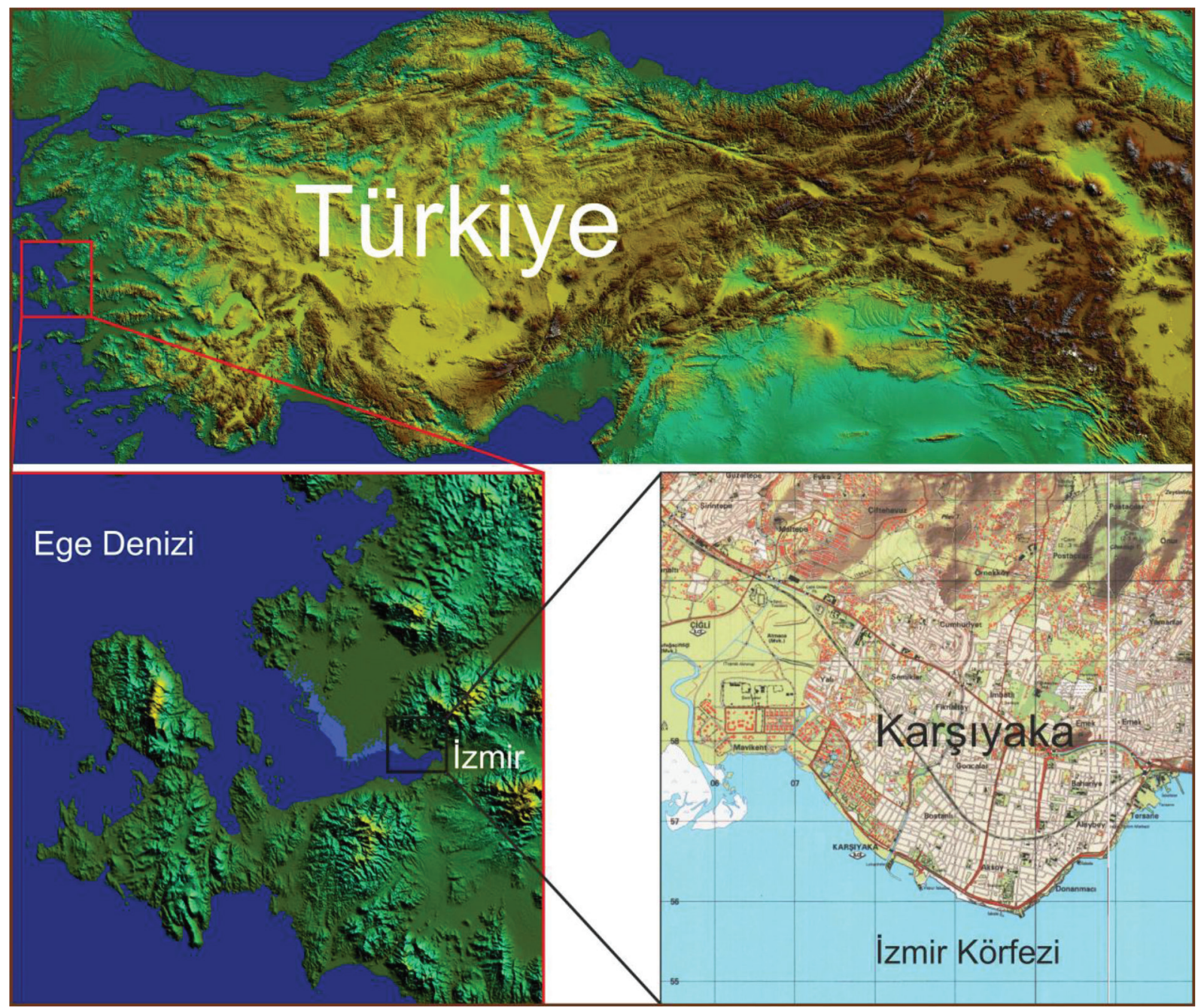

Şekil 1. Çalışma alanı yer bulduru haritası.

Figure 1. Location map of the study area.

Tüm yöntemlerden elde edilen sonuçların kendi aralarındaki uyumlarına ve jeolojik birimler de göz önüne alınarak ortak sonuçlara ulașılmaya çalıșılmıștır.

\section{JEOLOJi}

Çalışma alanı, Batı Anadolu içinde yer alan İzmir ilinin Karşıyaka ilçesi sınırları içerisinde yer almaktadır. Yamaç molozlarını inceleme alanını çevreleyen ana dereler ve ana derelere dik konumda yer alan küçük dereler boyunca görmek mümkündür. Yamaç molozları, temel kayalardan türeme blok ve çakıllar içeren kumlu siltli ve killi zemin özelliği sunmakta ve arazi genelinde görülmektedir.

Çalışma alanı içinde bulunan Karşıyaka Fayı, İzmir İç Körfezi'nin kuzey sınırını olușturur ve konumu itiba- rıyla Karșıyaka ilçesini kuzey ve güney olacak șekilde iki parçaya böldüğü söylenebilir (Şekil 2). BayraklıKarșıyaka ilçeleri arasında yaklașık D-B yönünde uzanan bu fay, Karșıyaka ilçesi sınırları içerisinde KB-GD uzanımlıdır. Fayın yükselen bloğundaki Miyosen yașlı volkanik birimler ve Bornova Karmașı̆ı'na ait birimler KD ve KB uzanımlı doğrultu atım bileșenli faylarla kesilmiștir. Karșıyaka Fayı'nın düșen bloğunun büyük bir kesimi İzmir Körfezi'nin suları altında kalmıștır (Sözbilir vd., 2008).

Karșıyaka Fayı, Bayraklı'dan Karșıyaka'ya kadar olan bölümde, önceki çalıșmalarda Yamanlar volkanitleri (Akdeniz vd., 1986) olarak bilinen Altıntepe volkanitleri, Sancaklı volkanitleri ve Dumanlıdağ grubundan olușan (Dönmez vd., 1998) Miyosen yașlı volkanik birimler ile Holosen çökellerini keser. Çalıșma alanının temel kayasını Bornova Karmașığı olușturmaktadır. 


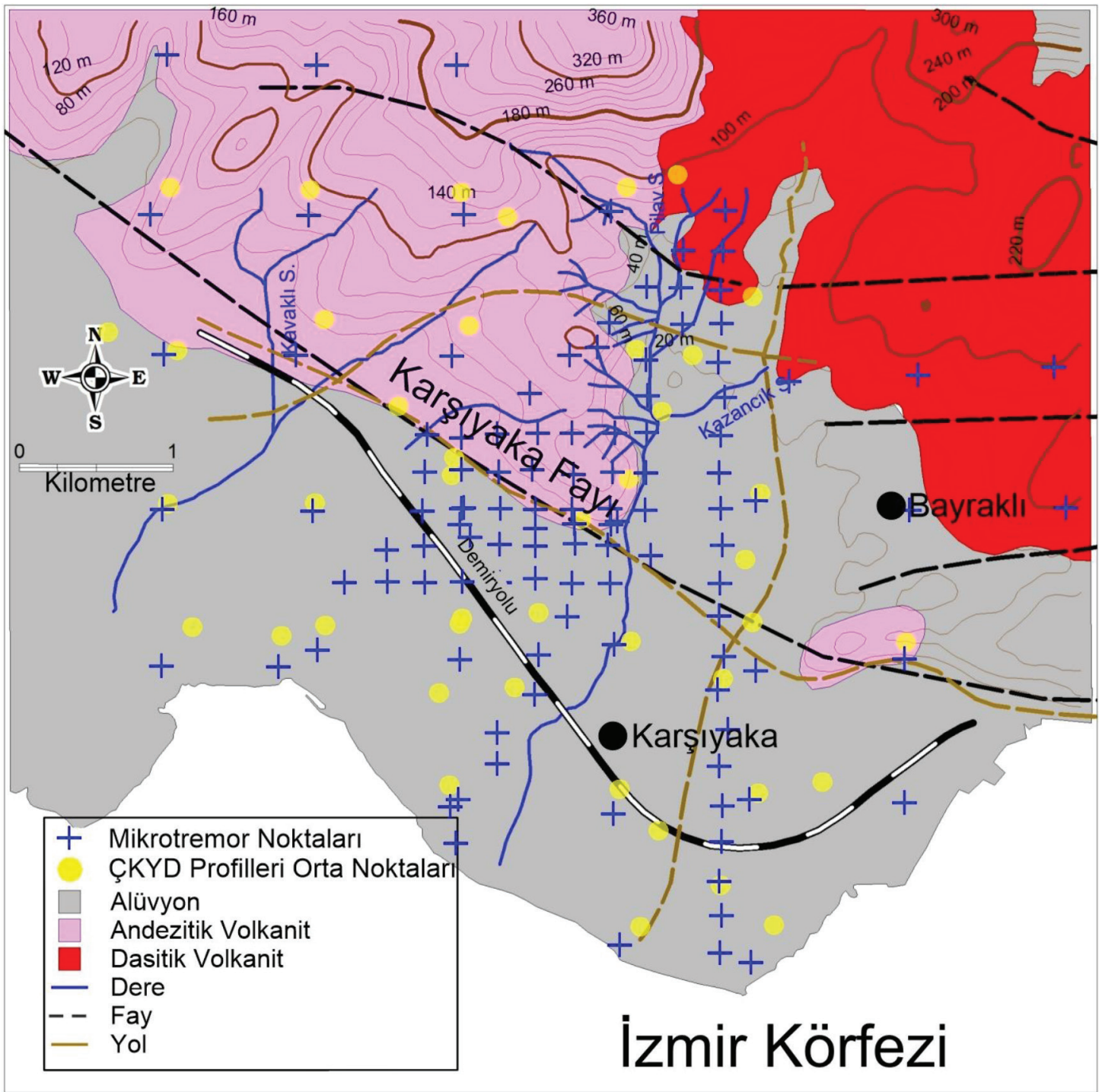

Șekil 2. Çalıșma alanı 1/25000 ölçekli jeoloji haritası (MTA, 2000'den değiștirilmiștir). Figure 2. 1/25000 scale geological map of the study area (modified from MTA, 2000).

Çalışma alanının kuzey kesimlerinde ise Yamanlar Volkanitleri yüzlek verirler ve andezitik-dasitik masif lav, tüf, otobreșik andezit ve aglomeralarla temsil edilirler. Volkanitler, bölgede bulunan Neojen çökellerini uyumsuz olarak üstlemektedir.

\section{JEOFIZIK ÇALIȘMALAR VE BULGULAR}

\section{ÇKYD Yöntemi Çalıșmaları}

ÇKYD yöntemi arazi çalışmaları farklı serim uzunluklarındaki 43 profil üzerinde yapılmıștır (Șekil 2). Saha koșullarına göre, jeofon aralıkları 1, 2.5 ve $5 \mathrm{~m}$, jeofon sayısı 24-48 adet jeofon olacak șekilde seçilmiștir.

Veri setleri Geometrics firması üretimi 24 kanallı sismik alıcı, $4.5 \mathrm{~Hz}$ kesme frekanslı düșey jeofon ve 100 Ib. hidrolik çekiç enerji kaynağı kullanılarak olușturulmuștur. 4.5 Hz'lik jeofonlar bir çok araștırmacı tarafından bu yöntemde sıkça kullanılmıștır (Park vd., 1999; Dikmen vd., 2010; Kanbur vd., 2011; Tunçel, 2014). Arazi çalıșması sırasında 0.125 ms örnekleme aralığı ile 2 sn süresince kayıtlar alınmıștır. Veri değerlendirme ișlemleri Seisimager programı kullanılarak yapılmıștır.

ÇKYD yöntemi verilerinin değerlendirilmesinde Ortak Orta Nokta Çapraz İlișki (CMPCC) analiz tekniği kul- 


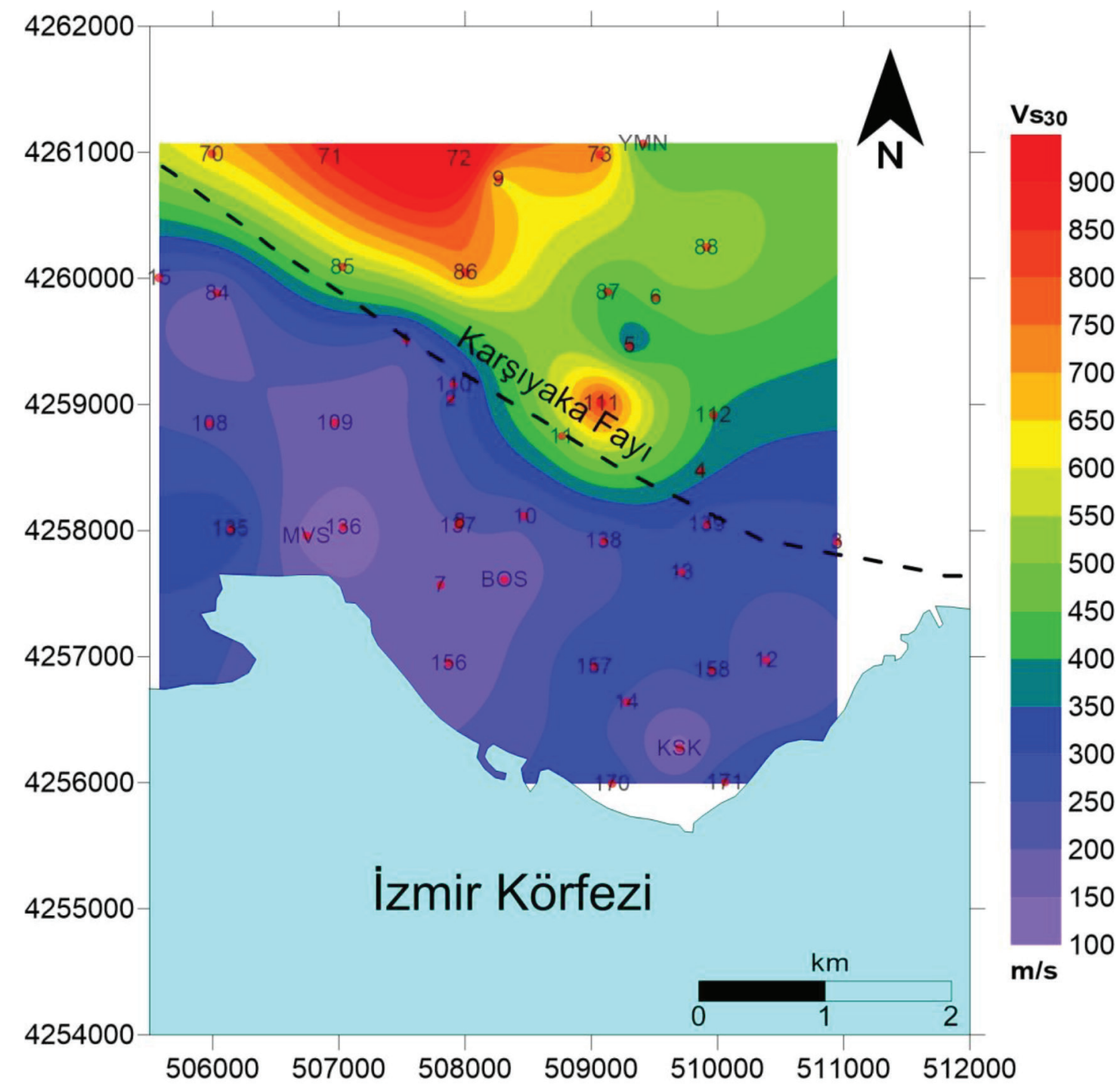

Șekil 3. ÇKYD yöntemi ile elde edilen $V_{s} 30$ hızları dağılım haritası (kırmızı noktalar ÇKYD yöntemi ölçüm profillerinin orta noktasını göstermektedir).

Figure 3. $V_{s} 30$ velocities distribution map obtained by the MASW method (red points indicate the center point of the MASW method measuring profile).

lanılmıștır (Hayashi ve Suzuki, 2004). Yüzey dalgası yöntemlerinde CMPCC toplam tekniği uygulanırken alıcı dizilimi içerisindeki alıcılar arasındaki orta noktalar eșleștirilir. Bu teknik kullanılarak aynı ortak noktada toplanan sinyaller üst üste bineceğinden analizlerde çözünürlüğün artması sağlanmaktadır. Bu bakımdan sismik yansıma yöntemindeki tekniklerle benzerlik göstermektedir. Analizlerde, her bir atıșa ait alıcı dizilimindeki alıcı çiftlerine çapraz korelasyon işlemi uygulanır ve bunlar daha sonra CMPCC toplamlar halinde sıralandırıır. Her bir CMPCC noktasında, eşit aralıklı çapraz korelasyona uğramış alıcılar zaman ortamında yığılır. Bu çalıșmada her profil için jeofon aralığı kadar seçilip birleştirilen tüm sismik kayıtların, faz hızı-frekans dönüşümleri yapılmıştır. Faz hızıfrekans dönüşümlerinden yararlanılarak dispersiyon eğrileri çizdirilmiştir. İşlemler sırasında düşük kaliteli veriler programda elenmiș ve dispersiyon eğrilerine yumușatma uygulanmıștır. Ters çözüm sonucunda $S$ dalgası hızının derinlikle değișimini gösteren 2 boyutlu (2B) modeller olușturulmuștur.

Çalışmanın devamında, her profil için elde edilen $\mathrm{V}_{\mathrm{s}} 30$ hızları kullanılarak çalıșma alanına ait $\mathrm{V}_{\mathrm{s}} 30 \mathrm{hız}$ dağılım haritası çizilmiştir (Șekil 3). Uygulama ala- 


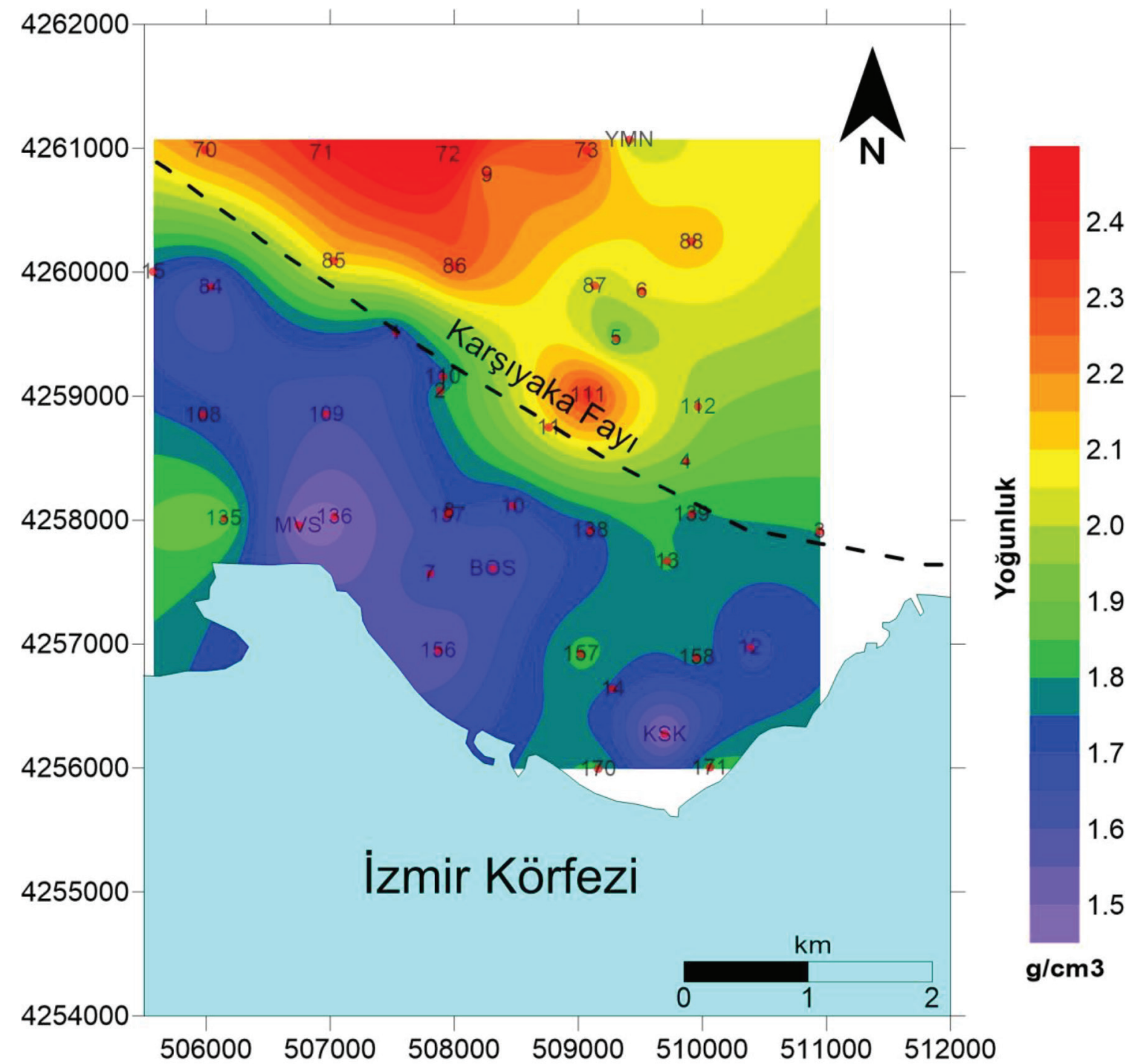

Şekil 4. ÇKYD yöntemi verisinden elde edilen makaslama dalgası hızları kullanılarak hesaplanan yoğunluk dağılımı (kırmızı noktalar ÇKYD yöntemi ölçüm profillerinin orta noktasını göstermektedir).

Figure 4. Calculated density distribution map using shear wave velocities obtained from MASW method (red points indicate the center point of the MASW method measuring profile).

nında 43 profilde $30 \mathrm{~m}$ derinliğe kadar elde edilen makaslama dalgası hızları kullanılarak $\rho=0.44^{\star} V_{S}^{0.25}$ (Keçeli, 1990) bağıntısından yoğunluk değerlerinin çalıșma alanındaki dağılımı haritalanmıștır (Șekil 4).

Zemin hâkim titreșim periyodu $\mathrm{T}_{0}=4 \mathrm{~h} / \mathrm{N}_{\mathrm{s}} 30$ bağıntısıyla $30 \mathrm{~m}$ derinliğe kadar hesaplanmıș ve alanın ZHTP dağılım haritası olușturulmuștur (Șekil 5). Bu yaklașımda jeolojik modelin zemin ve altındaki anakayadan olușacak șekilde 2 tabakalı olması ve zemin kalınlı̆ının en fazla $30 \mathrm{~m}$ olması kabulü geçerlidir. Çalışma alanında bazı yerlerdeki zemin kalınlıkları 30 metreden daha kalın olabileceği için bu yaklașımla hesaplanan değerler bu ortamların gerçek zemin hâkim titreșim periyotlarına yaklașım olarak değerlendirilebilir ve mikrotremor yöntemi ile ulașılan ZHTP değerleriyle kıyaslama yapmak amacıyla kullanılabilir. Zeminin sadece kalınıı̆ı ile $V_{s}$ hızına bağımlı olan karakteristik zemin periyodu, en önemli büyütmenin hangi titreşim periyodunda gelişeceği hakkında çok önemli bir belirteçtir (Kramer, 1996).

$\mathrm{V}_{\mathrm{s}} 30$ hızları dağılım haritası incelendiğinde çalışma alanının güney ve kuzey bölümleri birbirine göre 


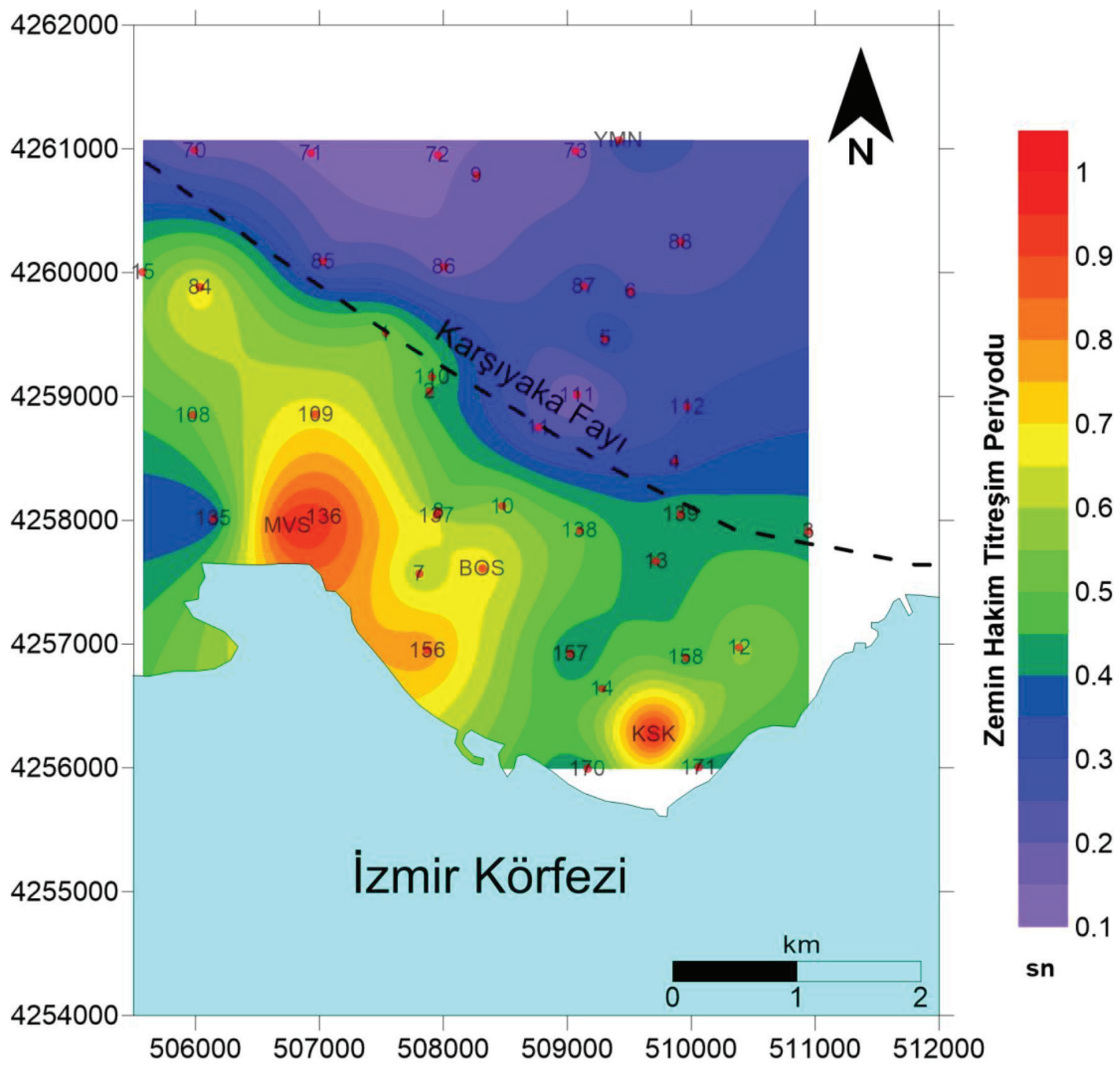

Şekil 5. ÇKYD yöntemi verisinden elde edilen makaslama dalgası hızları kullanılarak hesaplanan ZHTP dağılım haritası (kırmızı noktalar ÇKYD yöntemi ölçüm profillerinin orta noktasını göstermektedir).

Figure 5. Calculated PSP distribution map using shear wave velocities obtained from MASW method (red points indicate the center point of the MASW method measuring profile).

belirgin hız farklılıkları göstermektedir. Kuzeyden güneye doğru hızlar azalmakta ve en güneyde deniz kenarlarına yaklaşıldıkça $V_{\mathrm{s}} 30$ hızının $150 \mathrm{~m} /$ sn civarına düştüğü görülmektedir. Kuzeye doğru gidildikçe kademeli olarak hızlar artmakta ve 900 m/sn civarında en yüksek $V_{s} 30$ hız değerleri dağıIım haritasında gözlenmektedir (Şekil 3). V 30 hızları kullanılarak elde edilen yoğunluk dağılım haritasında ise çalışma alanının güney ve kuzeyinde birbirlerine göre yoğunluk kontrastı belirgin olup anomali uzanımlarının KB-GD yönlü olduğu gözlenmektedir (Șekil 4).
ÇKYD yönteminden elde edilen makaslama dalgası hızları kullanılarak hesaplanan ZHTP değerlerinin bölgede dağılımı Șekil 5'te verilmiștir. Çalıșma alanı yaklașık olarak KB-GD yönünde ikiye bölünürse kuzeyde kalan bölgede en fazla 0.4 sn süreli ZHTP değerleri gözlenirken güney bölgede daha uzun yaklașık $1 \mathrm{sn}$ değerlerine ulașan ZHTP değerleri görülmektedir.

\section{Mikrotremor Yöntemi Çalıșmaları}

Mikrotremor yöntemi ölçümleri ZHTP ve büyütme faktörü parametrelerini elde etmek ve diğer yön- 


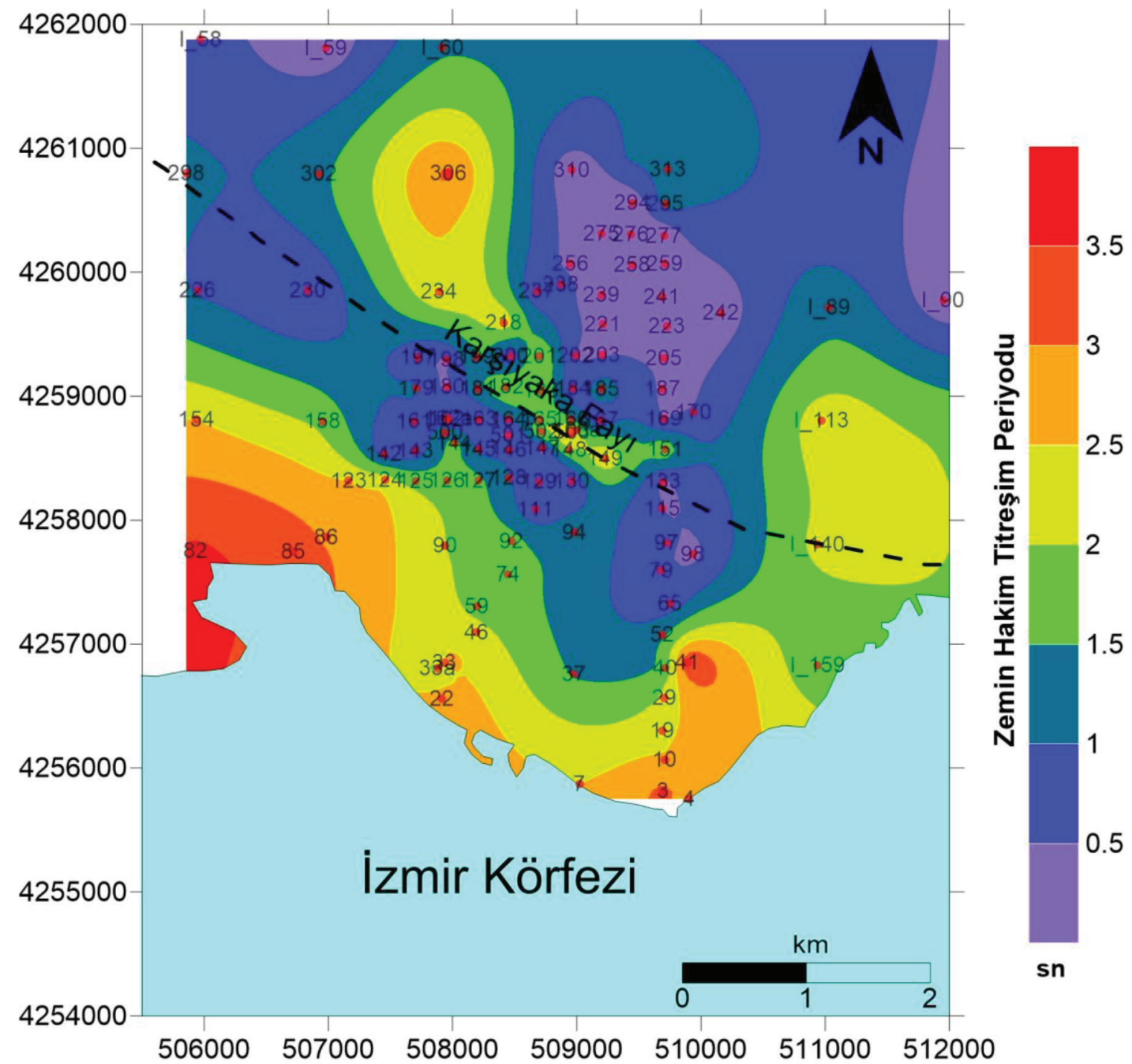

Şekil 6. Mikrotremor yöntemi verisi kullanılarak hesaplanan ZHTP dağılım haritası (kırmızı noktalar mikrotremor yöntemi ölçüm noktasını göstermektedir).

Figure 6. Calculated PSP distribution map using Microtremor method data (red points indicate the microtremor method measuring point).

temlerin sonuçları ile kıyaslama yapabilmek için uygulanmıştır. Bu amaçla çalıșmada veri toplamak için 3 bileșenli CMG-6TD hız kayıtçısı kullanılmıștır. Ölçümler Nakamura (1989) tek nokta tekniğiyle (HVSR) değerlendirilmiștir. Kayıt süresi yaklașık 30 dakika, örnekleme aralığı $100 \mathrm{~Hz}$ olacak șekilde çalışma alanında toplam 112 noktada veri toplanmıștır (Şekil 2). Ölçümler sırasında bozucu çevresel (rüzgar) etkileri azaltmak için kayıt cihazı üzeri kapatılarak veya gömülerek korunmuștur. Özellikle yoğun insan ve araç trafiğinin olduğu ölçüm noktalarında kayıtlar gece saatlerinde alınmıștır.
Mikrotremor yöntemi ölçümlerinden elde edilen ZHTP dağıım haritası Karșıyaka çalıșma alanı için Șekil 6'da verilmiștir. Verilerin değerlendirilmesi sonucunda elde edilen spektrumlardan okunan ZHTP değerleri çalıșma alanı için 0.1-3.5 sn değerleri arasında değișmektedir. Çalıșma alanının güneydoğu köșesinde birkaç noktada en yüksek periyot değerleri (3.5 sn) elde edilirken alanın genelinde 2 saniyeden daha düșük ZHTP değerlerine ulașılmıștır. Çalışma alanında jeolojik birim olarak Yamanlar Volkanitleri üzerinde yer alan kuzey ölçüm noktalarında düșük baskın periyot değerleri gözlenirken güneye (deniz 


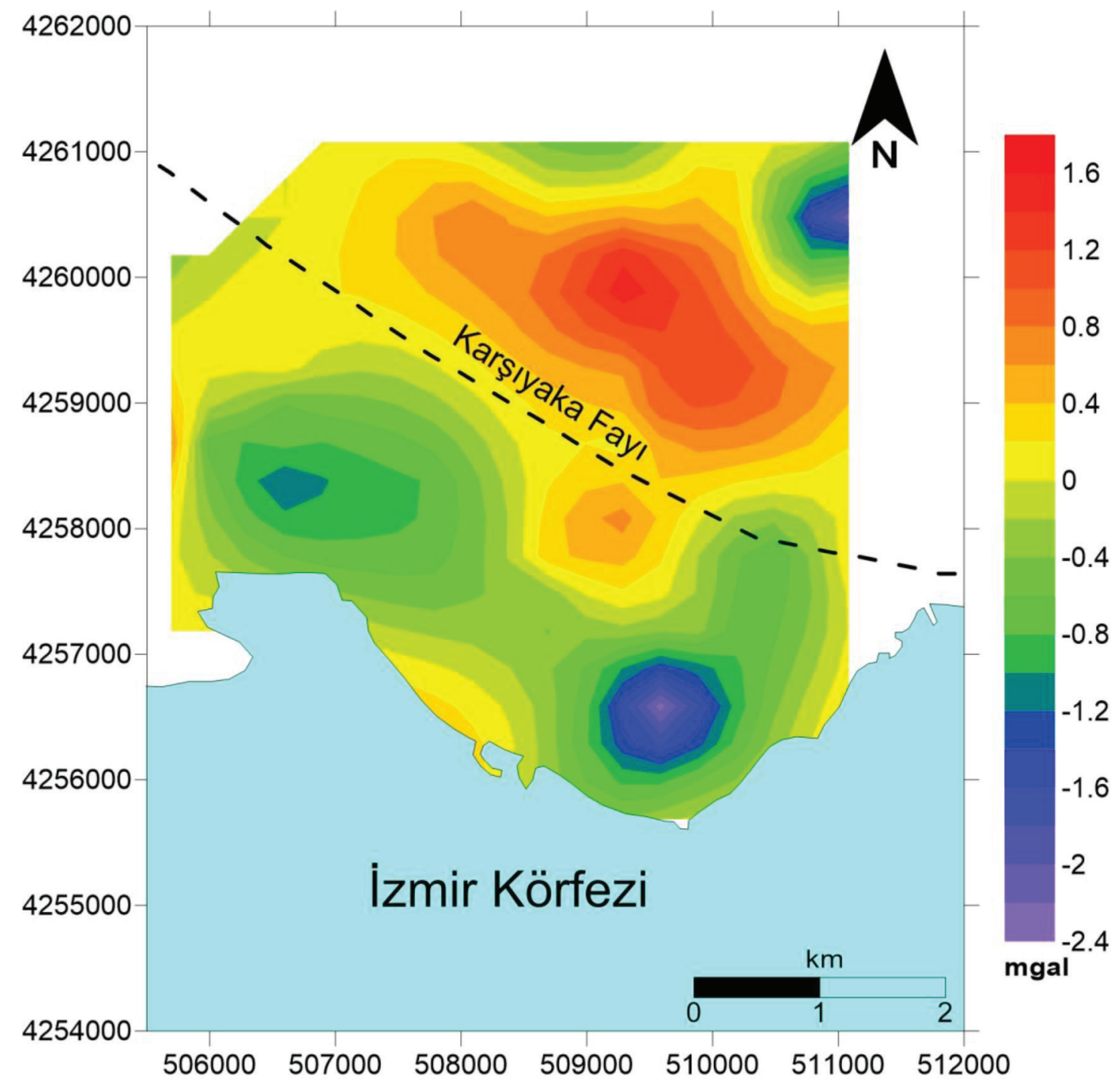

Şekil 7. İkinci derece trend uygulaması sonucu elde edilen Bouguer gravite anomali haritası. Figure 7. Bouguer gravity anomaly map obtained using second order polynomial application.

kıyısına) doğru daha yüksek (uzun süreli) baskın periyot değerleri gözlenmektedir.

\section{Mikrogravite Yöntemi Çalıșmaları}

Mikrogravite ölçümleri Scintrex CG-5 gravite cihazı kullanılarak saha koșullarına göre 250-300 m örnekleme aralığı ile gerçekleștirilmiștir. Ölçüm noktalarındaki yükseklik değișim bilgileri Cors-Tr bağlantılı olarak Leica $1200++$ GNSS cihaz seti kullanılarak toplanmıștır. Veri toplanması sırasında 60 sn süreli 5 tekrarlı okuma yapılmıștır. Ölçülen mikrogravite değerlerinden elde edilen Bouguer gravite anoma- li haritasında polinomal yaklașım kullanılarak farklı derecelerde rejyonel Bouguer gravite değerleri elde edilmiș ve bu değerler ölçülen değerlerden çıkarılarak, rezidüel gravite anomali değerleri elde edilmiștir. Saha geneline ait $V_{s} 30$ (Şekil 3) ve $T_{0}$ (Şekil 6) değerlerinden elde edilen haritalar esas alınarak hâkim anomali uzanım benzerliği ve anomalilerin dağılımı en uygun olan sonucun ikinci derece polinom değerlerinden elde edilen rezidüel anomali haritasına ait olduğu belirlenmiștir. Bu nedenle ikinci derece polinom uygulaması ile elde edilen bouguer gravite anomali haritası bu çalıșmada esas alınmıștır (Şekil 7). Elde edilen haritada anomaliler KB-GD yönlü olup 
yüksek ve düșük değerdeki genlikler kuzeyden güneye doğru ardalanmalı olarak gözlenmektedir. Yüksek genlikli anomali değerleri harita genelinde bölgenin kuzeyinde KB-GD yönlü, düșük genlikli anomali değerleri de yine aynı șekilde KB-GD yönlü olarak sahanın güneyinde gözlenmektedir (Şekil 7).

\section{TARTIȘMA VE SONUÇLAR}

Karșıyaka çalıșma alanında ÇKYD yöntemiyle yapılan arazi ölçümleri sonuncunda, alanda 100-900 m/ sn arasında değișen $\mathrm{V}_{\mathrm{s}} 30$ hızları elde edilmiştir. Makaslama hızlarının dağılımı alan genelinde kuzeyden güneye doğru azalma göstermektedir. Kuzeyde yer alan, jeolojik olarak Yamanlar Volkanitleri üzerine gelen ve alüvyon kalınlığının çok az olduğu düşünülen yerlerde makaslama dalgası hızlarında yüksek değerler elde edilirken, güneyde alüvyon birimler üzerinde hesaplanan değerlerde makaslama dalgası hızlarında düșme görülmektedir. Özellikle körfez kıyısına yakın kısımlarda makaslama dalgası hızları 150 $\mathrm{m} / \mathrm{sn}$ değerlerine kadar azalmıștır. Bu azalmanın sebebi alüvyon kalınlığının artması ile açıklanabilir.

Çalışma alanında ZHTP değerleri ÇKYD yöntemi ve mikrotremor yöntemi olmak üzere iki farklı jeofizik yöntemden elde edilen veriler kullanılarak hesaplanmıștır. Farklı yöntemler kullanılarak ulașılan sonuçlara bakıldığında her iki yöntem için de çalıșma alanının kuzeyinde ZHTP değerlerinin görece düșük, güneyinde ise görece yüksek olduğu görülmektedir. Elde edilen değerlerin yöntemler arası farklılık göstermesinin sebebi olarak, farklı araștırma derinliklerine sahip olmaları gösterilebilir. Bu çalıșma kapsamında ÇKYD yöntemi ile $30 \mathrm{~m}$ derinliğe kadar elde edilen veri değerlendirmeleri kullanilırken mikrotremor yöntemiyle zemin ile anakaya arasındaki sınır derinliğine kadar olduğu kabul edilen veri değerlendirmeleri kullanılmaktadır. Çalışma alanının güneyinde mikrotremor yöntemiyle hesaplanan ZHTP değerleri ÇKYD yöntemiyle hesaplanan değerlerden daha yüksektir. Bu farklılı̆ın bölgenin güneyinde zemin kalınlıklarının 30 metreden daha fazla olmasından kaynaklandığı düșünülmektedir.

Mikrotremor tek nokta ölçümleri ile elde edilen ZHTP değerlerinin 1 sn'den daha büyük olduğu yerlerde, $V_{s} 30$ hızlarının genellikle $700 \mathrm{~m} / \mathrm{sn}$ 'den daha düșük olduğu gözlenmiștir. Ölçüm noktasında ZHTP değerinin 1 sn'den büyük olmasının, anakaya derinliğinin 30 metreden daha fazla olmasından kaynaklandığı sonucuna da varılabilir.
Türkiye deprem yönetmeliğinde (DBYBHY, 2007) zemin sınıflama tablosunda kullanılan en büyük $T_{B}$ değeri 0.9 sn'dir. ZHTP'nin belirlenmesi durumunda zeminin alt ve üst hâkim periyotlarının yani spektrum karakteristik periyotlarını ampirik ilișkiler $\left(\mathrm{T}_{\mathrm{A}}=\mathrm{T}_{0} / 1.5\right.$, $T_{B}=T_{0^{*}} 1.5$ ) ile belirlemek mümkündür (Uyanık, 2015). Zemin hâkim titreșiminin 1 sn olduğu bir zeminde ilgili bağıntı ile $T_{B}$ değeri $1.5 \mathrm{sn}$ hesaplanır ve bu değer zemin sınıflama tablosundaki en büyük $T_{B}$ değerinden büyüktür. Yönetmelikteki tablo 0.9 sn'den büyük $T_{B}$ değerleri içermediğinden çalıșma alanında ZHTP değerleri kullanılarak hesaplanacak $T_{B}$ değerlerinin 0.9 sn'den büyük olduğu noktalarda zemin sınıfının tablo kullanılarak belirlenmesi mümkün olmayacaktır. $T_{B}$ değerinin 0.9 sn'den büyük hesaplandığı noktalarda zemin sınıfının belirlenebilmesi için yönetmelikte de belirtildiği gibi özel tasarım ivme spektrumları elde edilmelidir. Bu çalıșma kapsamında çalıșma alanında zemin sınıfı dağııımları hesaplanmamıștır.

Zemin kalınlığının 30 m'den fazla olduğu alanlarda yüksek katlı yapılar için rezonansa girme olasılı̆̆ı artmaktadır. Zemin kalınlığı arttıkça ZHTP değeri artar aynı șekilde bina yüksekliğinin artması da binanın periyodunu arttırmaktadır. Zemin ve bina periyotlarının birbirine yakın olması rezonans riskini arttıracağı için istenmeyen bir durumdur. Zemin kalınlığının fazla olduğu alanlarda yüksek katı yapılar inșa edilecekse, zemin tabakası kalınlığı doğru hesaplanmalı ve anakayaya kadar zemin transfer fonksiyonu (ZTF) elde edilmelidir.

Çalışma alanında uygulanan jeofizik yöntemlerden elde edilen dağılım haritaları (Șekil 3-7) incelendiğinde, alanın orta kısmında konturlarda gözlenen ani renk geçișlerinin KB-GD yönünde çizgisel olarak değișim gösterdiği dikkat çekmektedir. Bu çizginin kuzeyinde kalan bölgede makaslama hızı, yoğunluk ve gravite değerleri görece yüksek, bunlarla ters orantılı olarak ZHTP değerleri ise görece düșük değerler almıștır. Çizginin güneyinde kalan bölgede ise tüm parametreler kuzeyde elde edilen parametrelerin tam tersi yönde dağılım göstermektedir. Bu sonuçlardan yararlanarak çalıșma alanında saptanan sınırın çizimi Șekil 8'de verilmektedir.

Çalışma alanında bulunan Karșıyaka Fayı (Şekil 2) ve Şekil 8'de jeofizik yöntemler yardımı ile saptanan sınıın birbiri ile doğrultu ve konum bakımından çok benzer olduğu görülmektedir. Dolayısıyla jeofizik çaIıșmalar sonucunda elde edilen ve Şekil 8'de çizilen kırmızı renkli sınır, bölgeyi ikiye bölen bir fay zonunun varlı̆̆ı ile ilişkilendirilebilir. 


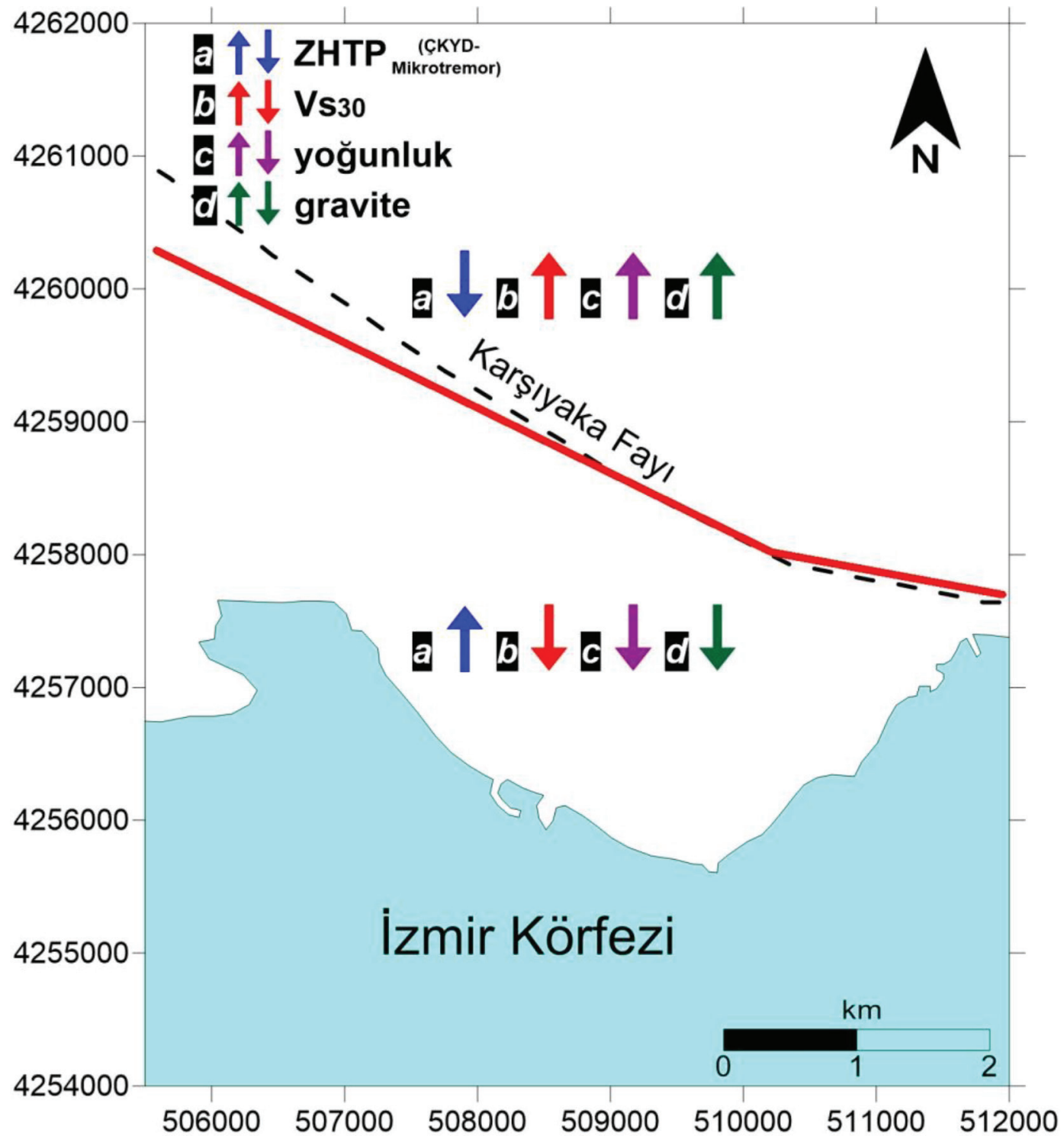

Şekil 8. Jeofizik yöntem sonuçlarının çalışma alanındaki değişimleri, kırmızı düz çizgi parametrelerin değişimine göre bölgeyi ikiye ayıran sınır.

Figure 8. Changes of the geophysical method results at the study area, red solid line separating the two regions according to changing physical parameters.

Bu çalıșma kapsamında mikrotremor kayıtları, 30 m derinliğe kadar olan makaslama dalgası hızları ve bu hızlarla hesaplanan parametreler ve ayrıca mikrogravite yöntemi ile elde edilen rezidüel Bouguer gravite anomalilerinin bölgedeki dağılımları elde edilip değerlendirilmiştir. Deprem dalgalarının kaynağından çıkıp anakaya ve zemin tabakalarında seyahat ettikten sonra binalara ulașması ile son bulan deprem olayını daha iyi analiz etmek için daha derin çalıșmalar yapılabilir. Bu çalıșma sonucunda tabakalar arası hız farklarından meydana gelen sismik empedans oranı değișimlerinin hesaplanabileceği derinliklere (anakaya derinliği) kadar jeofizik çalışmaların genișletilmesi önerilmektedir.

\section{KATKI BELIRTME}

Bu çalışma 2008-2011 yılları arasında yürütülen TÜBiTAK-KAMAG 106 G159 numaralı proje ve Dokuz Eylül Üniversitesi Bilimsel Araștırma Projeleri kapsamında 2009.KB.FEN.036 numaralı proje ile desteklenmiștir. Yazarlar, yayına öneri ve düzeltmeler 
ile katkı sağlayan hakemlere (Ünal Dikmen ve diğer anonim hakem) ve dergi editörlerine teșekkür ederler. Ayrıca yazarlar projelerde görev alanlara teșekkür ederler.

\section{KAYNAKLAR}

Akdeniz, N., Konak, N., Öztürk, Z. ve Çakır, M.H., 1986. İzmir-Manisa dolayının jeolojisi. MTA Rapor No: 7929, Ankara.

Aki, K., 1988. Local site effects on strong ground motion. Proceedings of Earthquake Engineering and Soil Dynamics II, Park City, Utah, 103-155.

Bolt, B.A., 1999. Earthquakes. NY: W.H. Freeman and Company.

Borcherdt, R.D., Wentworth, C.M., Janssen, A., Furnal, T. and Gibbs, J., 1991. Methodology GIS mapping of special study zones for strong ground shaking in the San Francisco Bay region. Proceedings 4th International Conference on Seismic Zonation, 3, 545552

DBYBHY, 2007. Bayındırlık ve İskan Bakanlığı, Deprem bölgelerinde yapılacak binalar hakkında yönetmelik. Resmi Gazete, Ankara.

Dikmen, Ü., Arısoy, M.Ö. and Akkaya, İ., 2010. Offset and linear spread geometry in the MASW method. Journal of Geophysics and Engineering, 7, 211-222.

Dönmez, M., Türkecan, A., Akçay, A.E., Hakyemez, Y. ve Sevin, D., 1998. İzmir ve kuzeyinin jeolojisi, Tersiyer volkanizmasının petrografik ve kimyasal özellikleri. MTA Rapor No: 10181.

Eurocode 8, 2004. Design provisions of structures for earthquake resistance. European Committee for Standardization, Brüksel.

Hayashi, K. and Suzuki, H., 2004. CMP crosscorrelation analysis of multi-channel surface-wave data. Exploration Geophysics, 35, 7-13.

Joyner W.B. and Furnal, T., 1984. Use of measured shear-wave velocity for predicting geological site effects on strong motion. Proceedings 8th World Conference on Earthquake Engineering, 2, 777-783.

Kanbur, Z.M., Silahtar, A. ve Özsoy, C. 2011. Sığ sismik yansıma, MASW, ReMi yöntemleri ile sığ yapıların incelenmesi: Isparta yerleşim merkezi kuzeyi pliyo-kuvaterner Çökel yapı örneği. Süleyman Demirel Üniversitesi Fen Bilimleri Enstitüsü Dergisi, 15 (3), 224-232.

Keçeli, A., 1990. Sismik Yöntemlerle Müsaade Edilebilir Dinamik Zemin Tașıma Kapasitesi ve Oturmasının Saptanması. Jeofizik Dergisi, 2, 83-92.

Kramer, S.L., 1996. Geotechnical Earthquake Engineering. Prentice Hall, Upper Saddle River, New Jersey, USA, ISBN 0-13-374943-6.

M.T.A., 2000. İzmir 1/25000 ölçekli jeoloji paftaları. MTA yayınları, Ankara

Nakamura, Y., 1989. A method for dynamic characteristics estimations of subsurfaceusing microtremors on the ground surface. Quarterly Report of Railway Technical Research Institute, Japan, 30, 25-33.

Park C.B., Miller R.D. and Xia J., 1999. Multichannel analysis of surface waves. Geophysics, 64 (3), 800-808

Sözbilir, H., Uzel, B., Sümer, Ö., Ersoy, Y.E., Koçer. T., Demirtaș, R. and Özkaymak, Ç., 2008. Evidence for a kinematically linked EW trending İzmir fault and NE trending Seferihisar fault: Kinematic and paleoseismological studies carried out on active faults forming the İzmir Bay, Western Anatolia. Geology Bulletin Turkey, 51, 91-114.

Uyanık, O., 2015. Deprem ağır hasar alanlarının önceden belirlenmesi ve șehir planlaması için makro ve mikro bölgelendirmelerin önemi. Süleyman Demirel Üniversitesi Fen Bilimleri Enstitüsü Dergisi, 19 (2), 24-38

Tunçel, A., 2014. Jeofizik yöntemlerle zemin-anakaya sınırının belirlenmesi ve dinamik zemin parametrelerinin elde edilmesi: Karșıyaka ve Güzelbahçe (İzmir) örneği. Doktora Tezi, Dokuz Eylül Üniversitesi Fen Bilimleri Enstitüsü, İzmir. 